\title{
BACTERIAL LOAD IN EXPRESSED AND STORED BREAST MILK OF LACTATING MOTHERS IN ABIA STATE, NIGERIA
}

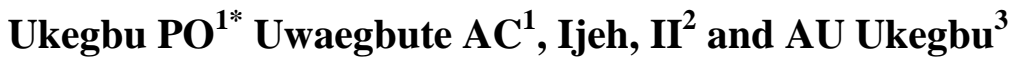

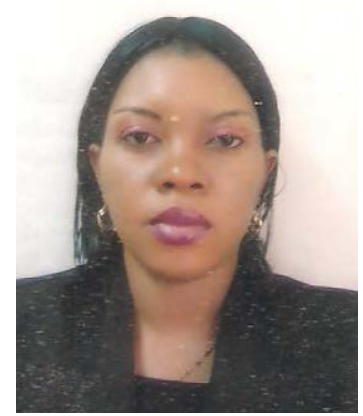

Patricia Ukegbu

*Corresponding author email: ukegbu.patricia@mouau.edu.ng

${ }^{1}$ Department of Human Nutrition and Dietetics, Michael Okpara University of Agriculture, Umudike, PMB 7267, Umuahia, Abia State, Nigeria.

${ }^{2}$ Department of Biochemistry, Michael Okpara University of Agriculture, Umudike

${ }^{3}$ Department of Community Medicine, Federal Medical Centre, Umuahia 


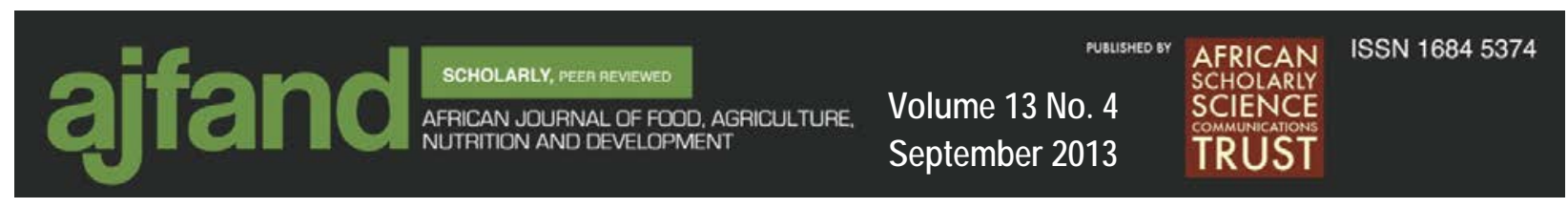

\section{ABSTRACT}

The use of expressed breast milk has been advocated as an effective way of encouraging and maintaining lactation when the mother is separated from the baby for a while. However, prospects of storage of expressed breast milk for any considerable period of time is hindered by the possibility of bacterial contamination and growth of infectious pathogens in the stored milk. Previous research worldwide has focused on optimal conditions for storing expressed breast milk. This study investigated bacterial growth in expressed breast milk stored at two different conditions and time periods. A total of 240 randomly selected lactating mothers participated in a survey used to elicit information on their practices concerning expressed and stored breast milk. Out of this, 20 lactating mothers were willing to donate their breast milk, which was used for microbial studies. Using antiseptic procedures, breast milk samples were collected from these 20 lactating mothers by manual expression and put into sterile containers. One half was stored at room temperature $\left(30^{\circ} \mathrm{C}\right)$, while the other half was immersed in a container of water $\left(26^{\circ} \mathrm{C}\right)$ for $0,3,6$ and $9 \mathrm{hrs}$. The samples at different time periods in both storage conditions were plated on three different culture media (Nutrient agar, MacConkey agar and Chocolate agar) and incubated for 24hrs. Bacterial load was enumerated and isolates were characterized and identified. Data was analyzed using one way ANOVA and presented as frequencies, percentages means and standard deviations. Results showed that in all the culture media, bacterial load was higher in breast milk samples stored at room temperature for up to 9hrs compared to that immersed in water $(\mathrm{p}<0.05)$. However, the average colony counts were within acceptable limits $\left(<10^{4} \mathrm{CFU} / \mathrm{ml}\right)$. Enterococcus faecalis, Escherichia coli and Staphylococcus aureus were the predominant bacteria isolated in the breast milk samples under both storage conditions. The findings from this study revealed that storage of breast milk either at room temperature or immersed in a container of water appeared to be safe for up to 9 hours of storage in a tropical environment. Generally, the number of microbes was within levels considered acceptable in expressed breast milk.

Key words: bacterial growth, expressed, breast milk 


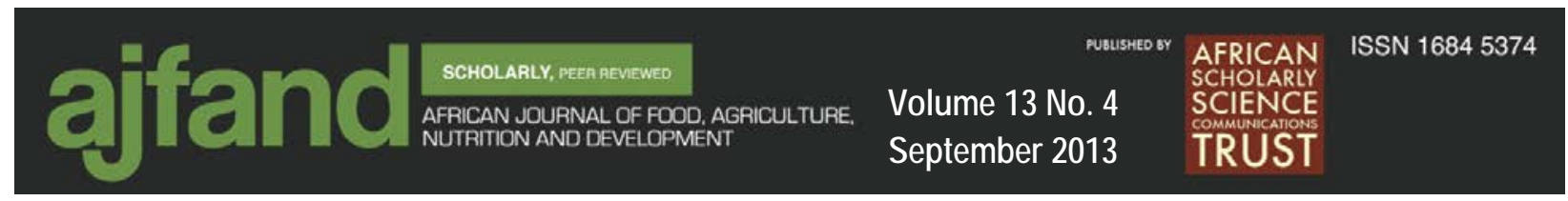

\section{INTRODUCTION}

The World Health Organization's [1] definition of exclusive breastfeeding is that an infant receive only breast milk from its mother or a wet nurse or expressed breast milk and no other liquid or solids with the exception of drops of syrups consisting of vitamins, mineral supplements or medicines. The practice of exclusive breastfeeding for six months requires that mother and infant be in close proximity for this period [2]. Expressed breast milk is advised to be given to the baby if the mother is to stay away from the child for long. However, the period of maternity leave in Nigeria lasts for only three months and at the same time crèches are not provided in the work places to promote exclusive breastfeeding. Mothers are thus encouraged to express breast milk and store it in containers [3]. If the nutritional value of the milk is to be conserved and infections prevented, it has to be stored within appropriate temperature range [4]. The length of time expressed breast milk can be stored at room temperature has thus been a cause for concern by mothers in this part of the world [3].

Achievement of optimal breastfeeding practices is further limited by the misconception that exists about expressed breast milk. Abosede and Esanbodo [5] noted that the practice was culturally unacceptable to Yoruba mothers, because they perceived that breast milk could easily be contaminated, poisoned or bewitched. A similar study noted that Yoruba fathers would not recommend expressed breast milk, because they believed it would become stale and sour [5].

Again, storage conditions may often not be optimal especially in a developing country like Nigeria, with tropical weather conditions. Storage (refrigeration and freezing) conditions may often not be optimal due to unreliable power supply. Moreover, majority of Nigerian mothers, particularly the rural and urban poor cannot afford refrigerators and freezers. They are thus limited to storage at room temperature. Most research on breast milk storage worldwide has focused on optimal conditions for storing breast milk [6,7]. To allay the fears of many mothers, this study assessed bacterial load in expressed breast milk under two storage conditions and length of time breast milk can be stored under these two storage conditions.

\section{MATERIALS AND METHODS}

\section{Samples}

The study was conducted among a group of lactating mothers attending immunization clinics for their infants at Community Medicine Department of the Federal Medical Centre (FMC), Umuahia. A total of 240 mothers consisting of mother-infant pairs who participated in a larger study on "Effect of maternal nutrition and body composition on lactation performance and breast milk composition" [8] were randomly selected. Oral and written consent was obtained from all mothers before commencement of the study. Ethical approval was obtained from the ethics committee of the Federal Medical Centre, Umuahia.

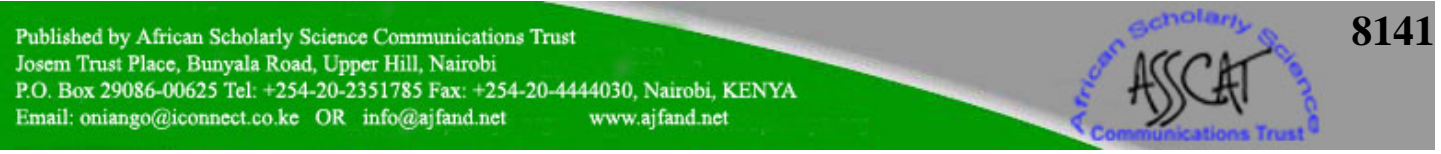




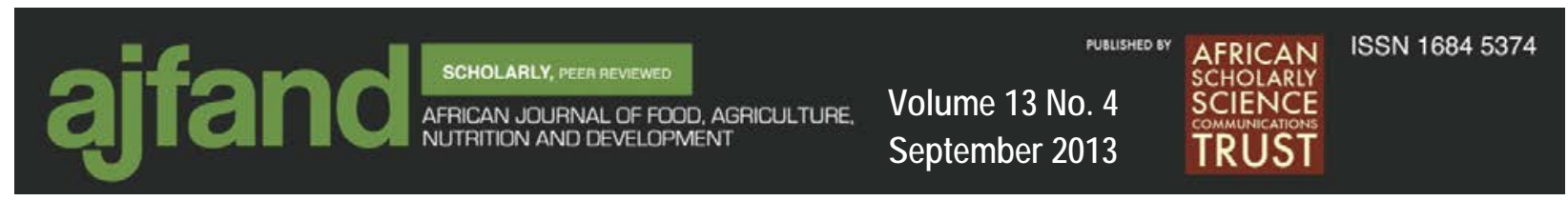

\section{Methods}

A structured questionnaire was distributed to the 240 randomly selected mothers. The questionnaire was used to elicit information on their practices concerning expressed and stored breast milk.

\section{Collection of breast milk samples}

Samples of breast milk were collected from 20 lactating mothers who willingly donated expressed breast milk samples. Inclusion criteria for participating in the study was that the mothers must have been lactating for a period of three months or more and have not been placed on antibiotics for up to six weeks before sample collection. The breast milk samples were collected by manual expression. The mothers were asked to wash their hands and nipples before expressing their breast milk. Each milk sample (10mls) was divided into two potions and put in labeled sterile sample bottles. Half of each fresh sample was stored at room temperature $\left(30^{\circ} \mathrm{C}\right)$, the prevailing room temperature during the study period, while the other half was immersed in a container of cold water $\left(26^{\circ} \mathrm{C}\right)$. The two storage conditions used were based on survey results of mothers on their mode of storing expressed breast milk. The samples were analyzed for types of bacteria and bacterial load after 0, 3, 6 and 9 hours of storage.

\section{Culture media}

The culture media used included nutrient agar, MacConkey agar and chocolate agar. The media were prepared according to the manufacturer's specifications. These media were sterilized in an autoclave at $121^{\circ} \mathrm{C}$ for 15 minutes.

\section{Isolation of microorganisms}

One (1) ml of each breast milk sample was serially diluted $\left(10^{-1}, 10^{-2}, 10^{-3}\right.$ and, $\left.10^{-4}\right)$. The dilution was properly shaken and a dilution of $\left(10^{-2}\right)$ was inoculated on sterile media for colony counting. Nutrient agar was used to isolate non fastidious organisms; chocolate agar was for isolating fastidious organisms, while MacConkey agar was used to differentiate between lactose and non-lactose fermenting organisms. These were incubated at $37^{\circ} \mathrm{C}$ for 24 hours. After 24 hours, a sterile wire loop was used to pick isolates from the plate and was streaked on freshly prepared nutrient agar, MacConkey and chocolate agar and then incubated for 24 hours at $37^{\circ} \mathrm{C}$ in order to get pure culture. After incubation, all colonies from a section of incubated plates were examined microscopically for Gram reaction, cell morphology and motility [9]. Biochemical analysis included catalase, oxidase and urease activities as well as indole test and patterns of sugar utilization. The isolates were identified based on the results obtained from biochemical characterization and microscopic examinations.

\section{Determination of $\mathbf{p H}$}

A pH meter (JENWAY 3505) was used to determine the pH levels of breast milk at different storage times under the two storage conditions according to methods of Onimawo and Egbekun [10].

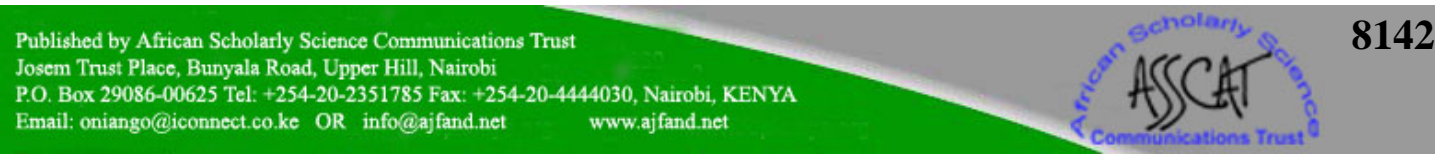




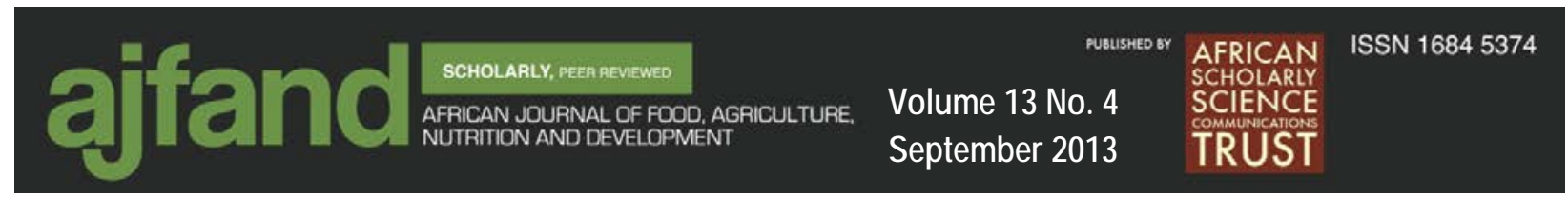

\section{Statistical analysis}

Data obtained was subjected to statistical analysis using SPSS version 15.0. Data was analyzed using one way ANOVA and presented as frequencies, percentages means and standard deviations. $\mathrm{P}<0.05$ was considered as statistically significant.

\section{RESULTS}

Table 1 shows the socio-demographic characteristics of the nursing mothers. More than two thirds $(71.3 \%)$ of the mothers were between the age range of $26-35$ years. Few mothers (7.9\%) had primary education. Others (42.9\% and $49.2 \%)$ had secondary and tertiary education, respectively. About one third (37.5\%) of the mothers were employed in the civil service, $21.7 \%$ were full time housewives, and 4.6\% were farmers. A high percentage (73.8\%) of mothers had between 1-3 children, 23.3\% had 4-6 children, 1.7\% had 7-9 children and only 1.3\% had between 10 and 12 children.

Practices of mothers on use and storage of expressed breast milk as shown in Table 2 revealed that most of the mothers (40.8\%) normally expressed breast milk and stored it whenever they had to leave their babies at home, while, $34.2 \%$ reported that they always go out with their babies. Others (25\%) reported that they use other liquids or semi solids in feeding their babies when away from home.

About $79.6 \%$ of the mothers reported that they used a feeding bottle, while $20.4 \%$ used a cup and spoon for feeding their infants. The expressed breast milk was commonly stored in the refrigerator by over half (52\%) of the mothers. Others stored by immersing the container of breast milk in cold water $(37.8 \%)$ or at room temperature (10.2\%). About half (55.1\%) stored for 1-2 hrs, over one third (35.7\%) stored for 3-4 hours, $6.1 \%$ for 5-6 hours and 3.1\% for 7-8 hours.

Table 3 shows the $\mathrm{pH}$ values for breast milk samples stored at different times. As presented, $\mathrm{pH}$ of samples stored at room temperature was not significantly different from those immersed in a container of water $(p>0.05)$. There was no significant difference in the $\mathrm{pH}$ of samples stored for different hours ( $\mathrm{p}>0.05)$.

The results of average number of colonies with respect to time and storage conditions are represented in Table 4. There were significant differences $(p<0.05)$ in colony counts of samples stored both at room temperature and immersed in water using the three media at $0,3,6$ and 9 hours. At baseline ( 0 hours) using the three media, no bacterial growth was detected under the two storage conditions. However, after 3 hours of storage, bacterial growth was evident in the samples under both storage conditions especially for those stored at room temperature. The result further showed that as the length of storage increased, bacterial load increased significantly especially between 0 and 9 hours of storage $(p<0.05)$. Average colony counts (CFU) were in the range of $0.00 \pm 0.00$ to $22.5 \pm 3.2 \times 10^{2} \mathrm{CFU} / \mathrm{ml}$ and $0.00 \pm 0.00$ to $7.8 \pm 5.6 \times 10^{2} \mathrm{CFU} / \mathrm{ml}$ for samples stored at room temperature $\left(30^{\circ} \mathrm{C}\right)$ and immersed in water $\left(26^{\mathrm{C}} \mathrm{C}\right)$, respectively.

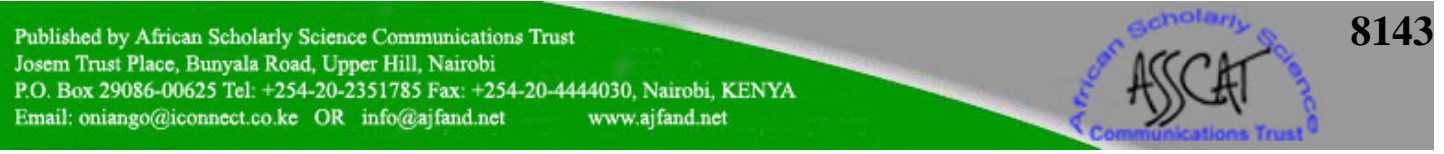


Characterization and identification of samples as presented in Table 5 showed that the predominant organisms isolated were Staphylococcus aureus, Escherichia coli and Enterococcus faecalis. The biochemical analysis showed that Staphylococcus aureus is Gram positive, motile and indole negative, catalase and coagulase positive and has sugar fermenting abilities. Escherichia coli is Gram negative, indole positive and coagulase negative, while Enterococcus faecalis is Gram positive, motile and coagulase negative, catalase negative and ferments glucose.

\section{DISCUSSION}

The use of expressed breast milk (fresh or frozen) has been noted to provide both nutritional and immunological benefits especially if its nutritional value can be conserved [4]. This becomes necessary when babies may be separated from the mothers due to maternal employment or schooling. In Nigeria, the period of maternity leave for working mothers lasts three months. Nursing mothers thus have to return to work after maternity leave, but some are not usually allowed by their employers to carry their infants to their places of work. Even where they do, no crèches are provided to enable the mother to breastfeed. It is thus encouraging in this study to find that some of the mothers would express breast milk and keep for their babies, while they are away from home. The use of expressed breast milk by some of these mothers is in line with WHO [1] definition of exclusive breastfeeding, and would go a long way to help maintain lactation, and encourage practice of exclusive breastfeeding for up to 6 months.

Contrary to findings of this study, a study among lactating women in Jos, Nigeria by Igbogboja et al. [11] observed that the mothers would not use expressed breast milk, because they believed that stored breast milk was unsafe after 6 hours of storage. Similarly, another study among the 'yoruba' tribe in Nigeria [5] reported that the practice of storing breast milk was culturally unacceptable to the group of mothers they studied, because the mothers perceived that stored breast milk could easily be contaminated, poisoned, bewitched or become stale and sour. However, it is possible that the populations used in these studies were less educated than those in the present study. Moreover, time difference may also be a factor, since there is now more information on Baby Friendly Hospital Initiative (BFHI) [12].

The expressed breast milk was more commonly stored in the refrigerator by over half (52\%) of the mothers. Others stored by immersing the container of breast milk in cold water $(37.8 \%)$ or at room temperature $\left(30^{\circ} \mathrm{C}\right)(10.2 \%)$. Studies $[13,14]$ have shown that the best method of storing expressed breast milk is in a refrigerator (at $4^{\circ} \mathrm{C}$ ) especially in hot climates. However, in a developing country like Nigeria, refrigerators are not usual household equipment in many homes. This, coupled with the epileptic electricity supply in these areas, makes this recommendation unrealistic, hence the necessity for alternative methods. This probably informed mothers to resort to storing breast milk in container of cold water. Other studies $[6,15,16]$ have been carried out under optimum conditions of storage and they noted that expressed breast

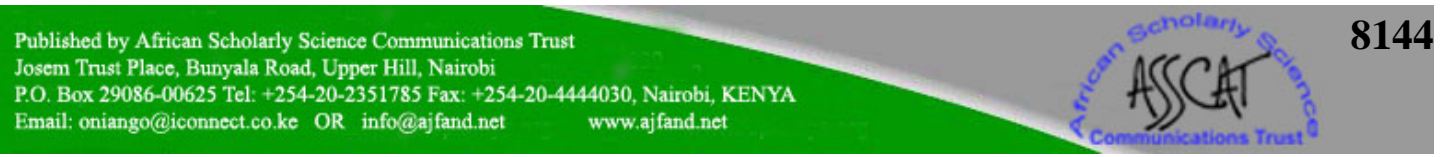


milk could last for up to 3-8 days in the refrigerator. Nigeria is characterized by relatively high temperatures throughout the year. The average annual maximum temperature varies from $35^{\circ} \mathrm{C}$ in the North to $31^{\circ} \mathrm{C}$ in the South, while the average annual minimum temperature in the South is $23^{\circ} \mathrm{C}$ [17].

The results on bacterial load revealed that breast milk samples analyzed immediately (0 hrs) had no bacterial growth in all the media used as well as under the two storage conditions. After the $3^{\text {rd }}$ hour of storage, bacterial growth was evident in samples stored at room temperature $\left(30^{\circ} \mathrm{C}\right)$, while none of the samples immersed in container of water $\left(26^{\circ} \mathrm{C}\right)$ had any form of growth in the three media used. By the $6^{\text {th }}$ and $9^{\text {th }}$ hour, however, bacterial growth was evident in all the samples on the different media under both storage conditions. The breast milk samples stored at room temperature $\left(30^{\circ} \mathrm{C}\right)$ and immersed in water $\left(26^{\circ} \mathrm{C}\right)$ had bacterial counts in the range of $0.00 \pm 0.00$ to $22.5 \pm 3.2 \times 10^{2} \mathrm{CFU} / \mathrm{ml}$ and $0.00 \pm 0.00$ to $7.8 \pm 5.6 \times 10^{2} \mathrm{CFU} / \mathrm{ml}$, respectively. The bacterial load was, however significantly lower in breast milk samples immersed in container of water $(\mathrm{P}<0.05)$. This implies that storage of breast milk samples under both conditions is good, but immersing in a container of cold water $\left(26^{\circ} \mathrm{C}\right)$ reduced bacterial growth. It is thus possible that the water used for storage had ability to inhibit bacterial growth within the first 3 hours of storage. This helped to delay or reduce bacterial growth in the breast milk samples. Similarly, Nwankwo et al. [18] reported that storage of expressed breast milk samples at room temperature would be of practical value to lactating women who do not have access to refrigerators, while Barger and Bull [19] reported that it would give poor lactating mothers the alternative of storing their breast milk out of refrigerators, at least for a limited period of time.

Bacterial counts of more than $10^{4} \mathrm{CFU} / \mathrm{ml}$ are regarded as unacceptable in breast milk $[20,21]$. Based on this, the levels obtained in this study after 9 hours of storage were within the acceptable range in breast milk. This implies that breast milk can safely be stored for up to 9 hours. Similarly, Moulin et al. [22] observed in their study that unprocessed breast milk stored at room temperature could safely be used after 9 hours of storage. Igumbor et al. [23] in a study conducted in Zimbabwe recorded colony counts of less than 200CFU/ml for breast milk samples stored at room temperature $\left(15-27^{\circ} \mathrm{C}\right)$ for 8 hours. This was, however, higher than values obtained in this study. The bacteria colonies obtained by Ajusi et al. [24] were low (ranging from 0.15-23.1 $\mathrm{x} 10^{3} \mathrm{CFU} / \mathrm{ml}$ with an average of $5.54 \times 10^{3} \mathrm{CFU} / \mathrm{ml}$ ). Their mean value was, however, higher than values obtained in this study.

Some potential pathogens such as Escherichia coli, Staphylococcus aureus and Enterococcus faecalis were isolated from the breast milk samples, though the levels were lower than recommended in breast milk $\left(<10^{4} \mathrm{CFU} / \mathrm{ml}\right)$. The isolated organisms are indicative of faecal contamination. A study [25] carried out on expressed breast milk stored in milk banks recorded bacterial growth with organisms such as Staphylococcus aureus and Escherichia coli and their presence in the milk samples was attributed to faulty milk management. Similarly, another study [24] isolated pathogenic microorganisms, such as Escherichia coli (26\%), Staphylococcus aureus

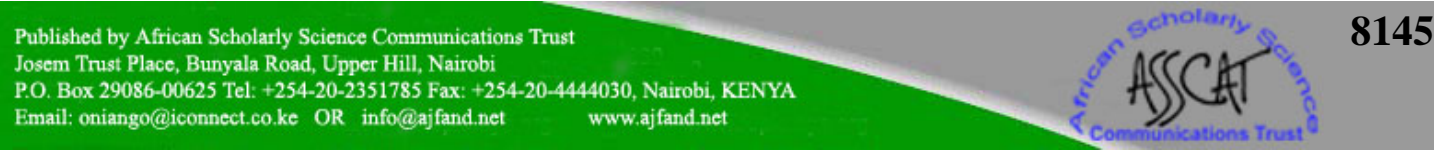




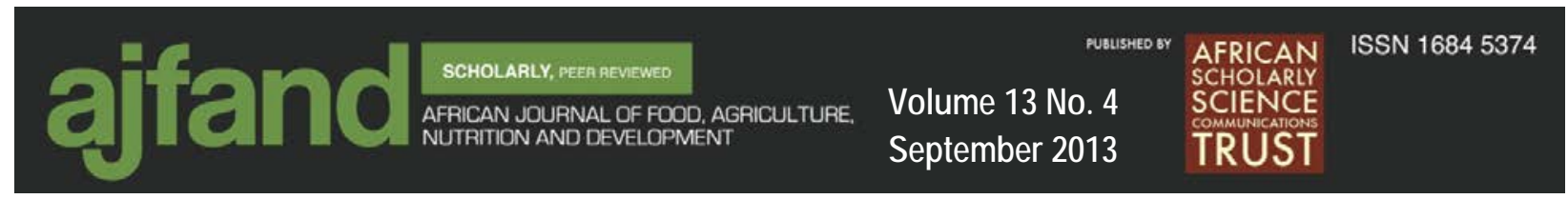

(6.7\%) and Enterococcus faecalis (13.6\%), but in small numbers in breast milk samples they analysed. In another study conducted in Nigeria that looked at bacterial growth in expressed breast milk stored at room temperature $\left(27-32^{\circ} \mathrm{C}\right)$ over a 24 hour period, the bacterial isolates represented normal skin flora [18]. The study further noted that at room temperature, mature milk could be stored for 6 hours without a significant increase in bacterial counts, while other studies [21,26] suggested 4 hours of storage in hot climates $\left(30-38^{\circ} \mathrm{C}\right)$. However, samples immersed in a container of water in this study were able to stay up to 3 hours, before microbial growth was detected.

During breastfeeding, the infant suckles directly from the mother's breast and this is supposedly free from contamination. However, expressed breast milk cannot be said to be entirely sterile or free from bacterial contamination [20,21,24,27]. This is because bacteria can enter into the milk during expression, through the equipment used [28] and even from the skin [18]. Eteng et al. [3] and Pardou et al. [29] observed that human milk containing fewer bacteria at the time of expression develops less bacteria growth during storage. Poor hygienic practices and improper washing of hands have also been implicated as possible sources of transmission of bacteria and viruses $[3,26,30]$. Another possible reason for the contamination in this study could be attributed to the warm temperature of the environment, which may encourage bacterial growth. Nwankwo et al. [18] noted that warm ambient temperatures were associated with faster growing bacterial counts in stored breast milk.

\section{CONCLUSION AND RECOMMENDATIONS}

Based on the data, this study has confirmed that storage of breast milk in a container of water and at room temperature may be safe for up to 9 hours as far as bacteriological quality is concerned. This is due to the low bacterial load encountered under both storage conditions. The importance of hygienic practices should however be emphasized to mothers during milk expression to avoid the risk of contamination. Findings from this study would be useful particularly for working mothers who may go back to work after the maternity leave period. This would encourage them to express and store breast milk for their babies before going to work and still be sure of its safety. It would also be of use to lactating mothers who do not have access to refrigerators and freezers for storage. This would encourage the practice of exclusive breastfeeding, as well as help maintain and encourage lactation.

\section{ACKNOWLEDGEMENT}

This research was supported by a grant from Academic Staff Union of Universities (ASUU) and the Federal Government of Nigeria (FGN) in collaboration with Federal Scholarship Board, Abuja (REF:FSBA/FGSS/PG/09/029). We thank the mothers who willingly participated in this study. We specially thank the staff of Community Medicine Department of the Federal Medical Centre, Umuahia who assisted in the study.

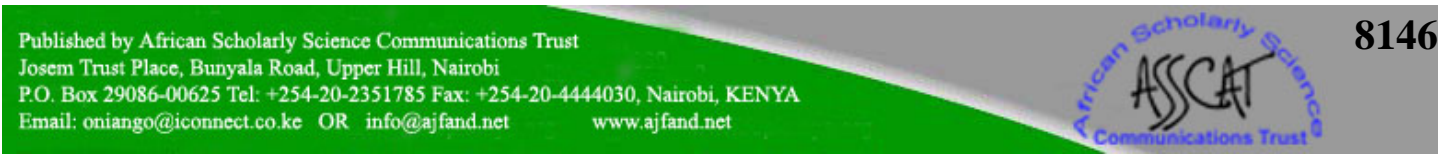


Table 1: Socio-demographic characteristics of lactating mothers $(n=240)$

\begin{tabular}{|c|c|c|}
\hline Parameters & Frequency & Percentages \% \\
\hline \multicolumn{3}{|l|}{ Age of mothers } \\
\hline $16-25$ & 51 & 21.3 \\
\hline $26-35$ & 171 & 71.3 \\
\hline $36-45$ & 18 & 7.5 \\
\hline Total & 240 & 100 \\
\hline \multicolumn{3}{|l|}{$\begin{array}{l}\text { Mother's educational } \\
\text { qualification }\end{array}$} \\
\hline Primary education & 19 & 7.9 \\
\hline Secondary education & 103 & 42.9 \\
\hline Tertiary education & 118 & 49.2 \\
\hline Total & 240 & 100 \\
\hline \multicolumn{3}{|c|}{$\begin{array}{l}\text { Mother's employment } \\
\text { status }\end{array}$} \\
\hline Civil servant & 90 & 37.5 \\
\hline Full time housewife & 52 & 21.7 \\
\hline Student & 37 & 15.4 \\
\hline Trader & 35 & 14.6 \\
\hline Artisan & 15 & 6.3 \\
\hline Farmer & 11 & 4.6 \\
\hline Total & 240 & 100 \\
\hline \multicolumn{3}{|l|}{ Parity } \\
\hline $1-3$ & 177 & 73.8 \\
\hline $4-6$ & 56 & 23.3 \\
\hline $7-9$ & 4 & 1.7 \\
\hline $10-12$ & 3 & 1.3 \\
\hline Total & 240 & 100 \\
\hline
\end{tabular}


Table 2: Practices of mothers on use of expressed and stored breast milk

\begin{tabular}{|c|c|c|}
\hline Parameters & Frequencies & Percentages \\
\hline \multicolumn{3}{|l|}{$\begin{array}{l}\text { Mode of feeding baby } \\
\text { when mother is away (0-6 months) }\end{array}$} \\
\hline Express breast milk & 98 & 40.8 \\
\hline Go out with baby and breastfeed & 82 & 34.2 \\
\hline Use other fluids/semi solids & 60 & 25 \\
\hline Total & 240 & 100 \\
\hline \multicolumn{3}{|l|}{$\begin{array}{l}\text { Container for feeding } \\
\text { expressed breast milk }(\mathrm{n}=\mathbf{9 8}) *\end{array}$} \\
\hline Cup and spoon & 20 & 20.4 \\
\hline Total & 98 & 100 \\
\hline \multicolumn{3}{|l|}{$\begin{array}{l}\text { Mode of storing/preserving } \\
\text { breast milk (n=98)* }\end{array}$} \\
\hline Container with cold water & 37 & 37.8 \\
\hline $\begin{array}{l}\text { At room temperature (on the } \\
\text { table/shelf) }\end{array}$ & 10 & 10.2 \\
\hline Total & 98 & 100 \\
\hline \multicolumn{3}{|l|}{$\begin{array}{l}\text { Duration of storage of expressed } \\
\text { breast milk }(n=98) *\end{array}$} \\
\hline 1-2 hours & 54 & 55.1 \\
\hline 3-4 hours & 35 & 35.7 \\
\hline 5-6 hours & 6 & 6.1 \\
\hline 7-8 hours & 3 & 3.1 \\
\hline Total & 98 & 100 \\
\hline
\end{tabular}

*Responses $\mathrm{n}=98$ 
Table 3: $\mathrm{pH}$ values of breast milk samples stored at room temperature $\left(30^{\circ} \mathrm{C}\right)$ and immersed in water $\left(26^{\circ} \mathrm{C}\right)$ at different storage times

\section{pH}

\section{Storage time (hrs) $\quad$ Room temperature $\left(30^{\circ} \mathrm{C}\right) \quad$ Immersed in water $\left(26^{\circ} \mathrm{C}\right)$}
0 hour
$8.1 \pm 0.02$
$8.1 \pm 0.01$

3 hours

$8.1 \pm 0.02$

$7.9 \pm 0.01$

6 hours

$8.0 \pm 0.01$

$7.8 \pm 0.04$

9 hours

$7.9 \pm 0.05$

$7.8 \pm 0.02$

P-value

$0.09^{\mathrm{ns}}$

$0.07^{\mathrm{ns}}$

ns =Values along the same column are not significantly different at $\mathrm{p}<0.05$ 
Table 4: Average number of colonies $(\mathrm{CFU} / \mathrm{ml})$ with respect to time of storage and storage conditions

\begin{tabular}{|c|c|c|}
\hline \multirow[t]{2}{*}{ Media } & \multicolumn{2}{|c|}{ Storage conditions } \\
\hline & Room temperature $\left(30^{\circ} \mathrm{C}\right)$ & Immersed in water $\left(26^{\circ} \mathrm{C}\right)$ \\
\hline Storage time (hrs) & CFU/ml & $\mathrm{CFU} / \mathrm{ml}$ \\
\hline NA 0 hours & $0 \pm 0.0^{\mathrm{a}} \times 10^{2}$ & $0 \pm 0.0^{\mathrm{a}} \times 10^{2}$ \\
\hline NA 3hours & $0 \pm 0.0^{\mathrm{a}} \times 10^{2}$ & $0 \pm 0.0^{\mathrm{a}} \times 10^{2}$ \\
\hline NA 6hours & $19.8 \pm 1.9^{\mathrm{b}} \times 10^{2}$ & $5.9 \pm 5.6^{\mathrm{ab}} \times 10^{2}$ \\
\hline NA 9hours & $22.5 \pm 3.2^{\mathrm{bc}} \times 10^{2}$ & $7.8 \pm 5.6^{\mathrm{bc}} \times 10^{2}$ \\
\hline P-value & $* 0.000$ & $* 0.050$ \\
\hline MCA 0 hours & $0 \pm 0.0^{\mathrm{a}} \times 10^{2}$ & $0 \pm 0.0^{\mathrm{a}} \times 10^{2}$ \\
\hline MCA 3 hours & $3.3 \pm 2.6^{\mathrm{a}} \times 10^{2}$ & $0 \pm 0.0^{\mathrm{a}} \times 10^{2}$ \\
\hline MCA 6 hours & $8.3 \pm 2.9^{b} \times 10^{2}$ & $1.8 \pm 1.7^{\mathrm{b}} \times 10^{2}$ \\
\hline MCA 9 hours & $9.8 \pm 4.1^{\mathrm{b}} \times 10^{2}$ & $5.2 \pm 0.5^{\mathrm{c}} \times 10^{2}$ \\
\hline P-value & $* 0.003$ & $* 0.000$ \\
\hline CHA 0 hours & $0 \pm 0.0^{\mathrm{a}} \times 10^{2}$ & $0 \pm 0.0^{\mathrm{a}} \times 10^{2}$ \\
\hline CHA 3 hours & $9.8 \pm 1.0^{\mathrm{b}} \times 10^{2}$ & $0 \pm 0.0^{\mathrm{a}} \times 10^{2}$ \\
\hline CHA 6 hours & $11.9 \pm 4.2^{b} \times 10^{2}$ & $2.8 \pm 2.2^{\mathrm{ab}} \times 10^{2}$ \\
\hline CHA 9 hours & $12.9 \pm 4.0^{\mathrm{b}} \times 10^{2}$ & $3.7 \pm 1.8^{\mathrm{bc}} \times 10^{2}$ \\
\hline P-value & $* 0.000$ & $* 0.029$ \\
\hline
\end{tabular}

*Values along the same column- for each media with different superscripts are significantly different at different storage times,

NA= Nutrient agar, MCA= MacConkey agar, $\mathrm{CHA}=$ Chocolate agar 
Table 5: Characterization and identification of micro-organisms

\begin{tabular}{llll}
\hline Sample & NA & MCA & CHA \\
\hline Gram & $+\mathrm{ve}$ & $-\mathrm{ve}$ & $+\mathrm{ve}$ \\
Motility & $-\mathrm{ve}$ & $+\mathrm{ve}$ & $-\mathrm{ve}$ \\
Catalase & $+\mathrm{ve}$ & $+\mathrm{ve}$ & $-\mathrm{ve}$ \\
Coagulase & $+\mathrm{ve}$ & $-\mathrm{ve}$ & $-\mathrm{ve}$ \\
Indole Test & $-\mathrm{ve}$ & $+\mathrm{ve}$ & $\mathrm{NT}$ \\
Oxidase sugar & $-\mathrm{ve}$ & $-\mathrm{ve}$ & $-\mathrm{ve}$ \\
Glucose & $+\mathrm{ve}$ & $+\mathrm{ve}$ & $+\mathrm{ve}$ \\
Sucrose & $+\mathrm{ve}$ & $+\mathrm{ve}$ & $+\mathrm{ve}$ \\
Maltose & $+\mathrm{ve}$ & $+\mathrm{ve}$ & $-\mathrm{ve}$ \\
Lactose & $+\mathrm{ve}$ & $+\mathrm{ve}$ & $+\mathrm{ve}$ \\
Arabinose & $-\mathrm{ve}$ & $-\mathrm{ve}$ & $-\mathrm{ve}$ \\
Mannitose & $+\mathrm{ve}$ & $+\mathrm{ve}$ & $+\mathrm{ve}$ \\
Sorbitose & $-\mathrm{ve}$ & $-\mathrm{ve}$ & $-\mathrm{ve}$ \\
Urease & $+\mathrm{ve}$ & $-\mathrm{ve}$ & - \\
& Staphylococcus & Escherichia & Enterococcus \\
& aureus & Coli & Faecalis \\
\hline
\end{tabular}

$\mathrm{NA}=$ Nutrient agar, $\mathrm{MCA}=$ MacConkey agar, $\mathrm{CHA}=$ Chocolate agar 


\section{REFERENCES}

1. WHO. Infant and young child nutrition. Global strategy on infant and young child feeding. 55 ${ }^{\text {th }}$ World Health Assembly. A 55/15. Geneva. 2002.

2. Moser-Veillon PB and RD Reynolds A longitudinal study of pyridoxine and zinc supplementation of lactating women. Am. J. Clin. Nutr. 1990; 52:135141.

3. Eteng MU, Ebong PE, Eyong EU and RR Ettarh Storage beyond three hour at ambient temperature alters the biochemical and nutritional qualities of breast milk. Afr. J. Reprod. Hlth. 2001; 5: 130-134.

4. Ezz EL, Din ZM, Ghaffer SA, Garby EK, Fahmi WA and RF Bedair Is stored and expressed breast milk an alternative for working Egyptian mother. Eastern Mediterranean Hlth. Journal 2004; 10 (6): 815-821.

5. Abosede OA and D Esanbodo Health education needs of fathers on breastfeeding: a study in Lagos, Nigeria. Nig. J. Nutr. Sci. 1986; 8: 1-15.

6. Zinn B Supporting the employed breast feeding mother. J. Midwifery Women's Hlth. 2000; 45: 216-226.

7. Recthman DJ, Lee ML and $\mathbf{H}$ Berg Effect of environmental conditions on unpasteurised donor human milk. Breastfeeding Medicine 2006; 1: 24-26.

8. Ukegbu PO Effect of maternal nutrition and body composition on lactation performance and breast milk composition. Ph.D Thesis. Michael Okpara University of Agriculture, Umudike 2012.

9. Cruickshank R, Duguid JP, Marimon BP and RNA Swain Medical Microbiology. $12^{\text {th }}$ ed. Churchill Livingstone, London, 1975.

10. Onimawo IA and KM Egbekun Comprehensive food science and Nutrition. Ambik Press Ltd. Nigeria. 1998: pp. 193-221.

11. Igbogboja IS, Odumodu CU and RS Olarewaju Breastfeeding pattern in Jos, Nigeria, before Baby Friendly Hospital Initiative. J. Trop. Pediatr. 1996; 42: 179-182.

12. Ogunlesi TA, Dedeke IOF, Okeniyi JAO and CM Oyedeji The impact of Baby Friendly Hospital Initiative on breast feeding practices in Ilesa. Nig. Journal of Pediatrics 2005; 32 (3): 46-51.

13. La Leche League International The breastfeeding answer book. $3^{\text {rd }}$ ed. Illinois, USA 2003. 
14. Martinez-Costa C, Silvestre MD, Lopez MC and A Plaza Effects of refrigeration on the bacterial activity of human milk: A preliminary study. $J$. Pediatr. Gastroenterol. Nutr. 2007;45 (2): 275-282.

15. Lawrence $\mathbf{R}$ and $\mathbf{R}$ Lawrence Breastfeeding: A Guide for the Medical Profession. Elsevier Mosby, Philadelphia, USA, 2005.

16. Tully MR Recommendations for handling of mother's own milk. J. Hum. Lact. 2000; 16: 149S-151S.

17. FGN. Avian influenza control and human pandemic: Preparedness and response project and medical waste management plan (Final report) 2007.

18. Nwankwo MM, Offor E, Okolo MA and JA Omene Bacterial growth in expressed breast milk. Ann Trop. Paediatr. 1988; 8 (2): 92-95.

19. Barger $\mathbf{J}$ and $\mathbf{P}$ Bull A comparison of the bacterial composition of breast milk stored at room temperature and stored in the refrigerator. Intl. J. Childbirth Ed. 1987; 2: 29- 30.

20. Deodhar L and S Joshi Microbiological study of breast milk with special reference to its storage in milk bank. J. Postgrad. Med. 1991; 37 (1): 14-20.

21. Cook P Handling and storage of expressed breast milk. MCN. 2006; 10-12.

22. Moulin ZS, Lamounier JA, Vieira MB, Baeta M, Silva MA and RS Araujo Bacterial contamination of breast milk collected through manual expression and stored at room temperature. Journal de Pediatrica 1998; 74 (5): 376-382.

23. Igumbor EO, Mukura RD, Makandiramba B and V Chihota Storage of breast milk: effect of temperature and storage duration on microbial growth. Centr. Afr. J. Med. 2000; 46 (9): 247-51.

24. Ajusi JD, Onyango FE, Mutanda LN and N Wamola Bacteriology of unheated expressed breast milk stored at room temperature. East African Medical Journal 1989; 66: 381-387.

25. Novak FR, Junqueira AR, Dias Mde S and JA Almeida Sensorial analysis of expressed breast milk and its microbial load. J. Pediatr (Rio J) 2008; 84 (2): 181-185.

26. Hamosh M, Ellis LA, Pollock BS, Henders MS and $\mathbf{P}$ Hamosh Breastfeeding and the working mother: Effect of time and temperature of short-term storage on proteolysis and bacterial growth in milk. Pediatr. 1996; 97 (4): 492-498. 
27. Rosolen CDC, Goulart AL and BI Kopelman Is breast milk collected at home suitable for raw consumption by neonates in Brazilian public intensive care units? J. Human Nutr. 2006; 22: 418-425.

28. Bio NY, Nordiah AJ, Allizali H, Nor-Rohaini AH and VK Lim Contamination of breat milk obtained by manual expression and breast milk pumps in mothers of very low weight infants. J. Hosp. Infect. 2001; 49: 274281.

29. Pardou A, Serruys E, Mascart-Lemone F, Dramaix M and HL Vis Human milk banking: influence of storage processes and of bacterial contamination on some milk constituents. Biol. Neonate 1994; 65: 302-311.

30. Hands A Safe storage of expressed breast milk in the home. MIDIRS Midwifery Digest. 2003; 13: 378-385. 